\title{
Improving Students' Writing Recount Text Ability Through Literacy-Based Teaching
}

Jamiluddin Jamiluddin

Department of Language and Arts Education, Faculty of Teacher Training and Education, Tadulako University, Indonesia

Corresponding Author: Jamiluddin Jamiluddin ,E-mail: jamiluddininggris@yahoo.co.id

\section{ARTICLE INFORMATION}

Received: December 04, 2020

Accepted: January 17, 2021

Volume: 3

Issue: 1

DOI: 10.32996/jhsss.2021.3.1.4

\section{KEYWORDS}

Improve the ability of; write recount text; literacy-based teaching

\section{ABSTRACT}

The purpose of this study was to determine how the process of implementing literacy-based teaching and learning can improve the students' ability of SMP Negeri 12 Palu in understanding and writing accurate and correct recount text. Therefore, this research design is a class action research that is cycled by implementing literacy-based teaching and learning through action planning, implementation, observation, and reflection procedures. If the first cycle is unsuccessful (not yet complete), then proceed to the second cycle with strategies for improving action planning, implementation, observation, and reflection. The data collection instruments were through observation, tests, and questionnaires. The subjects of this study were 12 Grade 8 students of SMP Negeri 12 Palu. In the first cycle, the classically average student score was 43.75 , meaning that it did not meet the minimum completeness criteria. After reflection through improving action planning and implementation in the classroom by applying teaching materials in oral and written form simultaneously or simultaneously in the second cycle, the students' mean score classically became 76.25 , which means that they meet the minimum completeness criteria set at State Junior High Schools. 12 Palu. The results showed that literacy-based teaching and learning could improve students' understanding in writing recount text correctly and correctly through implementing teaching materials in oral and written forms simultaneously or simultaneously.

\section{Introduction}

One of the activities in the development of educational personnel resources carried out by the Ministry of National Education several years ago is "Integrated Competency-Based" training for English teachers at junior high schools (SLTP). In teaching material development activities, the Indonesian government has issued a competency-based curriculum of English teaching materials and literacy-based teaching methods and approaches.

The effort made by the Ministry of Education and Culture of the Republic of Indonesia is nothing but a determination to develop the quality of English education, especially in junior high schools (SLTP). Mastery of English as a functional skill at the secondary school level is not only on receptive language skills but also on productive skills. However, these two types of gifts are not maximally understood and understood by students if they are not accompanied by useful teaching methods and approaches that are easy to understand and understand. This problem is well-founded both theoretically and empirically.

Theoretically, Jack and Renandya (2002) say that the influence of teaching English is very strongly determined by the approaches, methods, procedures, and learning techniques themselves. This clearly shows that the teacher's learning approaches, processes, and practices are very dominant in determining the success of learning and teaching in the classroom. Furthermore, it is said that if the policies, procedures, and teaching methods make learners (students) happy, it will create a comfortable, attractive academic atmosphere and ultimately motivate the learners (students) to be more active and passionate about learning. In the end, it will also lead to the right intrinsic motivation. As well as students' extrinsic motivation.

K C AL-KINDI CENTER R D FOR RESEARCH AND R D DEVELOPMENT Your gateway to world-class research

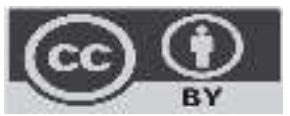

Published by Al-Kindi Center for Research and Development. Copyright (c) the author(s). This open access article is distributed under a Creative Commons Attribution (CC-BY) 4.0 license 
Theoretically, English teachers are expected to have a good understanding of the principles of teaching and evaluate the effectiveness of teaching materials and teaching procedures. This is very reasonable because, according to Brown (2001) that the role of the teacher in the classroom must function as a 'manager' who can manage and regulate the learning process in the school, knowing the needs of learners (students) which can make learners more excited about the ongoing lessons.

Empirically, several findings, among others by Amanah Sulaiman (2003), revealed that high school students' ability to understand productive skills is far from expectations. This is because they (students) only rely on memorizing the English material being taught without understanding it much more deeply. The students only understand superficially, not to understand the messages conveyed in the given English learning materials.

Another practical reason, namely based on pre-observations in class and the informal interviews with English teachers at SMP Negeri 12 several months ago in 2020, revealed some experiences that teachers did not have a clear picture of how to synchronize the method. And an approach that suits students' needs, especially methods and techniques for teaching productive skills (listening and writing) to overcome the inability to express ideas, both verbal and written statements, in the correct and correct form of 'recount text'. This has an impact on students' English scores shallow.

Finally, another practical reason from the researcher's observations concludes that teachers in their learning at this level tend to be 'text book-oriented' and not related to students' daily lives. Students have difficulty understanding academic concepts, namely using something abstract. As a result, student learning motivation is difficult to generate, and their learning patterns tend to memorize and mechanic. Based on some of these theoretical and empirical findings, the researcher offers a "literacy" based on learning and teaching. These learning and teaching sharpen the focus of "contextual" learning principles or what is commonly called "contextual teaching and learning" or abbreviated as CTL. This learning principle is none other than how English education, especially at the junior high school level, is much better than before.

The teaching and learning principles are based on 'literacy'; some teachers in Palu City have understood it because several workshops have been held related to this learning. The participants are junior high school teachers. This learning workshop started in seminars from 2006 to 2012, but so far, there has not been a full evaluation of the success of this "literacy" based teaching and learning model. Therefore, the researcher conducted class action research to test the success of 'literacy' based on teaching and learning in improving the ability to understand and write the text 'Recount' for students of SMP Negeri 12 Palu as one of the subject matters. They.

In the previous description, it seems that there are problems in teaching and learning English of SMP Negeri 12 students, especially the learning material for 'recount' texts, which must be minimized by their (students') disabilities in both the oral aspect (speaking) and the writing element (written form). The text type. This issue must receive immediate attention and handling because, in general, the subject matter at the junior high school level is concerned with the kinds of texts (text genders). Based on the theory and empirical findings in schools, one of the factors that can hinder students' understanding of learning recount texts is implementing teaching and learning in the classroom. Therefore, the researcher applies an approach through the techniques and models of teaching and learning based on "literacy" both on the linguistic aspect and on the "writing" aspect of the material for the students' recounts of SMP Negeri 12 Palu.

Of course, the researchers hope that this literacy-based learning model can minimize students' mistakes in understanding 'recount' texts. Thus, the formulation of this classroom action research is: How can the application of "literacy" based teaching and learning improve SMP Negeri 12 students' ability to write "recount" text?

This type of text is a text that tells a story, action, or activity (recount text is a text that describes the reader about one story, action, or training). The purpose of this text is to retell true stories from the past and entertain its readers. "Recount text" is usually used to tell an event in the past, so it's written using the past tense (action verbs), using adverbs and adverbial phrases, using "conjunction" and time connectives. The general structure of recount text is orientation, events, and reorientation.

In connection with 'Literacy' based learning and teaching, Kern (2000) provides a principal objective that can be applied in classroom teaching practice, namely 'literacy' involving interpretation, collaboration, convention, cultural knowledge, problemsolving, reflection, and language use.

In implementing this "literacy" based teaching and learning, the cycle stages include; Building Knowledge of the Field (BKOF), Modeling of Text (MOT), Joint Construction (JT), and Independent Construction (IC). These four stages are passed in each cycle, 
namely the oral cycle and the written cycle. Of course, the provision of 'recount text' teaching material does not stand alone. Still, the condition of teaching material is in the form of oral (orally) and written (written form) by applying the oral and written cycles.

In the teaching and learning process in the classroom based on literacy, the initial process is how students are led to build context (BKOF) and ends with creating a written text, namely 'recount' text. Thus, 'creation' and 'individual construction' become vital, as long as the process is literacy-based and contextual colors the activities. The application of 'literacy' based learning begins with spoken language and gradually leads to written form so that teachers are needed to stimulate students to interact verbally. Activities in the classroom do not only focus on 'writing' but also on speaking activity.

In this study, we also want to find out how much the students' ability to understand and write 'recount' texts are excellent and correct, using the right 'generic structure,' the general structure of the recount text, and the right 'language feature.' Doughty and Williams (2004) state that one of the aspects of language that provides a lot of assistance to learning English is grammar, especially in the communication process, both orally and in writing. Therefore, in the application of literacy-based learning and to improve understanding of the 'language feature,' what is most sought is the oral cycle.

\section{Methodology}

This research uses a class action research design, which the steps of this research follow the action research formulation of Kemmis (1982) as follows.:

Figure 1. Flow of Classroom Action Research Steps.

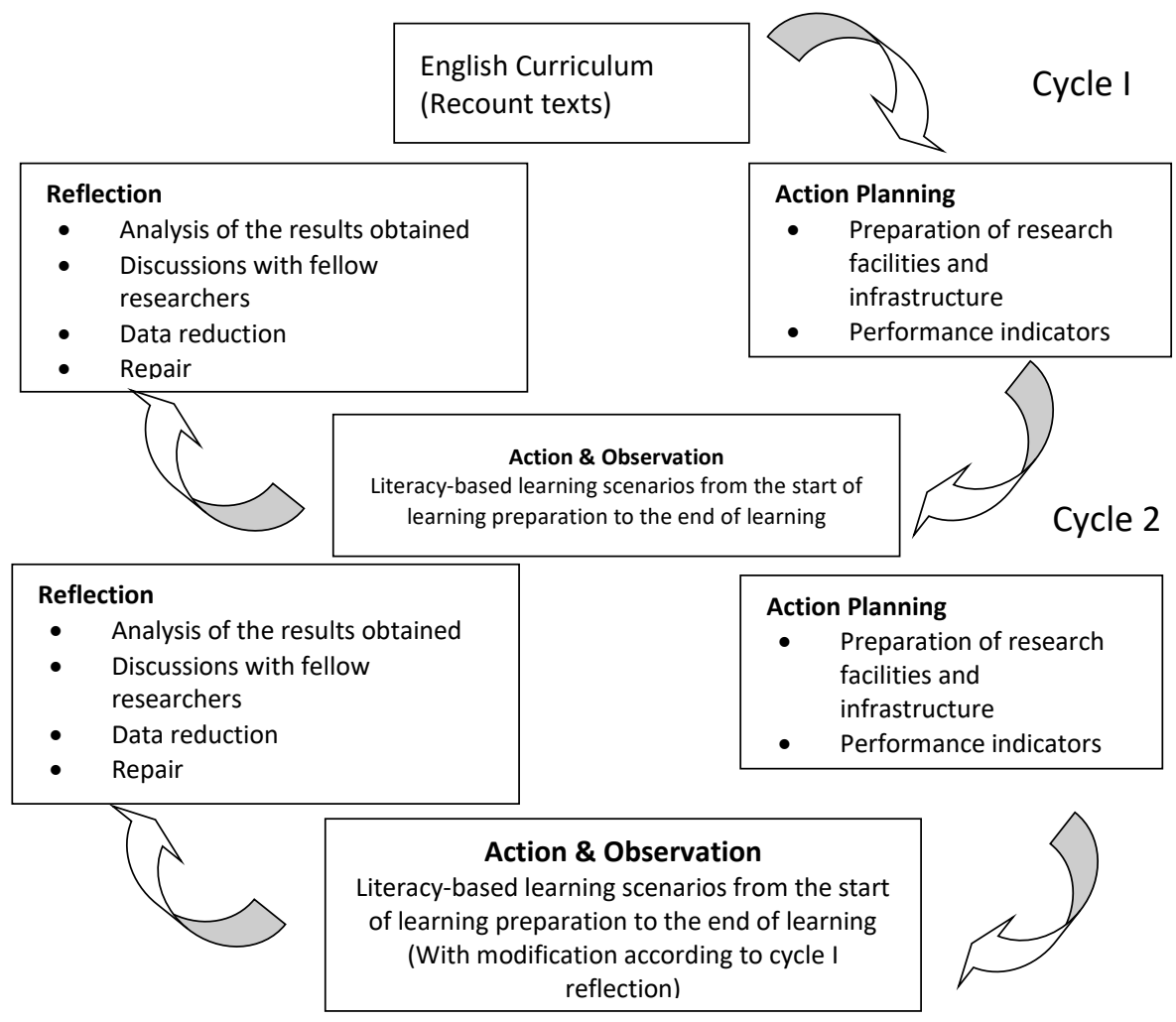

This research is planned to use 2 (two) significant cycles. Cycle I (first) is scheduled for Semester I, the New Academic Year 2019/2020. Revolution I (first) aims to reveal whether 'literacy' based on teaching and learning can improve the understanding and writing of 'recount text' correctly and correctly. In this cycle, a problem-solving plan is also designed, and its application to student learning. Furthermore, process II (second) is carried out after completing cycle I, namely at the beginning of October 2020, by evaluating the impact of implementation in the process I (first). Based on these evaluation results, a new design was compiled to be implemented in process II (second) and evaluated the effects. The collected data will be analyzed qualitatively and quantitatively. The data obtained from observations, questionnaires, interviews, and field notes were analyzed and interpreted qualitatively, while the data from the test results were analyzed quantitatively by scoring the following test results: 
Table 1. Scoring System and Test Result Value

\begin{tabular}{cll}
\hline Aspects being evaluated & Score & 20 \\
\hline 1. & The text structure is in the form of orientation & 30 \\
\hline 2. & Text structure in the form of Events & 20 \\
\hline 3. & Text structure in the form of reorientation & 30 \\
\hline 4. $\quad$ Linguistic elements in the form of tenses, action verbs, adverbs, and connective words' & Total score & $\mathbf{1 0 0}$ \\
\hline
\end{tabular}

The criteria for success in this classroom action research are determined based on the number of students who get a nominal value of 75 and above (good and very good classification) as much as 75 percent. This is based on the minimum completeness criteria that have been set at SMP Negeri 12 Palu.

\section{Results and Discussion}

Researchers present research results and discuss research results simultaneously to make it easier for researchers to analyze research data obtained through data collection instruments used in this study. There are two types of data received, namely qualitative data and quantitative data. Qualitative data were obtained from the students' teaching and learning process by collecting the data through observation instruments, field notes, questionnaires, and school documents. For quantitative data obtained from the evaluation test at the end of each cycle.

\section{CYCLE 1}

Tabel 2. Observation Results of Student Participation in Class

\begin{tabular}{|c|c|c|c|c|c|}
\hline \multirow[t]{2}{*}{ No } & \multirow[t]{2}{*}{ Observed problem } & \multirow[t]{2}{*}{ Descriptor } & \multicolumn{3}{|c|}{ Category } \\
\hline & & & $\mathrm{Rd}$ & Sd & $\mathrm{Tg}$ \\
\hline 1 & Enthusiastic students & $\begin{array}{l}\text { Students are passionate and enjoy } \\
\text { learning }\end{array}$ & $2(16.67)$ & $4(33.33)$ & $6(50.00)$ \\
\hline 2 & Student motivation & $\begin{array}{l}\text { Students are motivated to do } \\
\text { group work and have active } \\
\text { discussions }\end{array}$ & $1(6.33)$ & $4(33.33)$ & $7(58.33)$ \\
\hline 4 & Student understanding & $\begin{array}{l}\text { Students find it easier to } \\
\text { understand material in the form of } \\
\text { literacy }\end{array}$ & $0(00)$ & $3(25)$ & $9(75)$ \\
\hline 5 & Student response & $\begin{array}{l}\text { Students respond to teacher } \\
\text { wishes quickly }\end{array}$ & 1(6.33) & $8(66.67$ & $2(16.67)$ \\
\hline
\end{tabular}

The data above shows three category options to determine student participation in learning and teaching based on "literacy". These three categories can be seen about students' psychological factors by analyzing the components observed, namely students students' enthusiasm in participating in the learning process in class, student motivation, student attractiveness, student understanding, student responses, and student progress. Of the 12 students treated, the average student had a high response in each category (Tg) except for the "student response'response' component, only answer high response (Tg). Overall, the observed parts show that with literacy-based learning and teaching, students generally have a passion for learning both in their interest in education and in response to activities carried out by researchers in the classroom. It can also be said that all students participated positively in the written cycle and the oral process.

The results of the researcher's researchers' notes when inviting one of the students who represented the group to write down the group work, they helped each other. Likewise, they were excited to present the recount text orally that they worked on as a group. However, there are things that they sometimes find difficult to do, namely forms of "pluralization" and "singularity", for example, "I bought some book," "We saw many birds." This is understandable because of the influence of students students' Indonesian language interference. Therefore, the next treatment researcher always gives examples that the students can easily understand, such as "yesterday I saw two students of SMP Negeri 12 in front of my house". "Last night, My mother cooked two 
big eggs for me," and so on. This kind of sentence form is often presented to students, so they are accustomed to seeing and the "past tense tense' state of the sentence and the "pluralization" form.

Furthermore, the data obtained from the field notes will be cross-checked with observations. From the results of field notes, as far as the researchers observed before teaching and learning activities began, students chat with each other about the subject matter previously given. Some students are entirely indifferent. The researchers know that these students did not mention the subject matter at all 'recount text. These students only have stories that have nothing to do with the lesson. But overall, they generally exchange information, and even they chat like a short vocabulary, a grammar which is very difficult for him. Researchers heard these things and recorded their conversation results before the learning activity (treatment) began. On another note, they sometimes mention easy-to-understand learning methods or methods of learning, and so on. Overall, these field note results are not much different from the data from the several observed components' observations.

Another thing that was obtained from the field notes was that students often expressed their ignorance of vocabulary, so that they sometimes experienced stagnation in making recount texts. Likewise, researchers sometimes hear from their talk about the general structure of the recount text. Sometimes among the students treated, some act as mentors who provide instructions and teach other students who do not yet know about compiling an excellent and correct 'recount' text.

After implementing literacy-based learning and teaching activities for three meetings, individual student ability tests were given to measure and determine the learning outcomes and teaching based on 'literacy' applied to students. The test result data will become a reference and a reflection on the application of literacy-based education, whether it needs revision or improvements in learning planning before taking action (treatment) in class. The test results are as follows:

Table 3. First Cycle Student Test Results

\begin{tabular}{|c|c|c|c|c|c|c|c|}
\hline \multirow[t]{3}{*}{ No } & \multirow[t]{3}{*}{ Inisial } & \multicolumn{5}{|c|}{ Score } & \multirow[t]{3}{*}{ Category } \\
\hline & & \multicolumn{4}{|c|}{ Aspek Penilaian } & \multirow[t]{2}{*}{ Total } & \\
\hline & & Or. & Ev. & Reo. & Aspects of $\mathrm{Kb}$ & & \\
\hline 1 & $\mathrm{DA}$ & 20 & 15 & 15 & 10 & 60 & moderate \\
\hline 3 & WD & 15 & 10 & 10 & 5 & 40 & failed \\
\hline 4 & $\mathrm{DH}$ & 10 & 5 & 10 & 5 & 30 & failed \\
\hline 7 & $\mathrm{HS}$ & 15 & 10 & 10 & 5 & 40 & failed \\
\hline 8 & $\mathrm{FF}$ & 10 & 10 & 10 & 0 & 30 & failed \\
\hline 9 & WW & 15 & 10 & 15 & 10 & 50 & failed \\
\hline 10 & RS & 10 & 5 & 10 & 5 & 30 & failed \\
\hline 11 & RA & 10 & 10 & 10 & 10 & 40 & failed \\
\hline
\end{tabular}

Information: Or = Orientation, $\mathrm{Ev}=$ Event, Reo = Reorientation, and $\mathrm{Kb}=$ language

It has been previously established that the four main aspects become the assessment of good and correct 'recount' writing skills through literacy-based learning and teaching. The four main elements are the text structure in the form of orientation, the text structure in the form of events, the text structure in the form of reorientation, and linguistic elements in the form of tenses, action verbs, adverbs, and 'time connective.' The data obtained from the test results of the students' ability in making and writing recount text, on average, still experienced difficulties by the general structure of the recount text, such as determining the three available forms of the text. This can be seen from the test results obtained; it is illustrated that generally, students get a score from each of these aspects $50 \%$ of the errors made, that is, all students get scores below the completeness standard, some students get below the point 50 .

Whenever we also pay attention to the linguistic elements contained in 'recount text,' such as the use of 'simple past,' the use of 'pluralization' and 'singularity,' it seems that in general, it has very significant errors. This is evidenced by the data obtained from the tests given in the first cycle; all students made mistakes below $50 \%$ of the total score in the "language aspect," while about other aspects, students experienced errors that were evenly distributed, both in parts. 'orientation,' 'events,' and in the 'reorientation' aspect. The data above shows that students' understanding of writing recount text is shallow because it spreads to all parts assessed in this study. 


\section{Reflection}

In principle, the way the researcher (teacher) teaches 'recount' text-based on 'literacy' has fulfilled the procedures and stages of 'literacy' learning. Still, the classroom situation is sometimes uncontrollable (noisy) when the researcher asks for discussion or sharing opinions between students and other students (pase JCOT). Some also sit back and relax without responding to their peers, and these students are not encouraged or motivated by the researcher (teacher), so that their understanding of this text is not optimal. Some of the students were too prominent among their peers, and there was no attempt by the researcher (teacher) to exchange the central discussion pairs with their less active students.

Regarding the presentation or discussion of the material, sometimes it takes too long to explain a part of the material that shouldn't take too long, and vice versa; the explanation should be somewhat in-depth, but researchers do not do it so that the available time allocation is not balanced. Regarding the students' absorption of the material being taught is still low, so that it is necessary to carry out oral exercises (speaking), but it is still minimal by researchers. Likewise, sentence writing exercises are always separate from the daily context of the students. For example, sentences in everyday students' context help to write because it is based on their own experiences.

Based on the results of reflections from researchers and input from other researchers as observers, it is necessary to revise or improve teaching material that is more attractive to students and strives for each group member to be exchanged, not monotonous in the group, thus eliminating the gap between one group of students and a group of other students. Teaching material as far as possible is contextual, which is often experienced by students and is 'willing,' meaning that it is a daily condition that students often feel. There is also a need to apply literacy-based learning to begin teaching with an oral cycle and then a writing cycle. Still, it should be combined or used simultaneously, according to the classroom situation.

The reflection results also need to group in a group of students who understand faster and students who are slow to understand the material so that the process of sharing understanding between students occurs. In other words, it is necessary to group students competently so that good interaction can occur as well. Likewise, the examples given in the sentence must be related between one sentence and the next sentence so that at the end of the exercise, a text in the form of 'recount has been formed. From the results of other researchers' observations, when other researchers (teachers) carry out teaching activities in class, it is agreed to improve and revise the teaching material through mutual agreement. The forms of training must be changed before entering the next cycle.

\section{CYCLE 2}

Table 4. Observation Results of Student Participation in Class

\begin{tabular}{|c|c|c|c|c|c|}
\hline \multirow[t]{2}{*}{ No } & \multirow[t]{2}{*}{ Observed problem } & \multirow[t]{2}{*}{ Deskriptor } & \multicolumn{3}{|c|}{ Kategori } \\
\hline & & & $\mathrm{Rd}$ & Sd & $\mathrm{Tg}$ \\
\hline 1 & Enthusiastic students & Students are passionate and enjoy learning online & - & $\begin{array}{l}6 \\
(50.00)\end{array}$ & $6(50.00)$ \\
\hline 3 & Student attraction & Students often ask to understand it & - & $\begin{array}{l}2 \\
(16.67) \\
\end{array}$ & $10(83.33)$ \\
\hline 5 & Student response & Students respond to teacher wishes quickly & - & - & $12(100.00)$ \\
\hline 6 & Student progress & Students understand more about making assignments & - & - & $\begin{array}{l}12 \\
(100.00)\end{array}$ \\
\hline
\end{tabular}

The data above shows three category options to determine the development of student participation in learning and teaching based on 'literacy.' From these three categories, it can be seen about the psychological factors of students by analyzing the components observed are students' enthusiasm in participating in the learning process in class, student motivation, student attractiveness, student understanding, student responses, and student progress. Of the 12 students treated, the average student responded in each category of medium (sd) and high ( $\mathrm{Tg}$ ). Overall, the observed components show that with literacy-based learning and teaching, students generally have a passion for learning both in their interest in education and in response to activities carried out by researchers in the classroom. It can also be said that all students participated positively in the written cycle and the oral process. Only one student has low motivation. 
The results of these observations are very encouraging, but of course, they must be proven by the results of tests carried out at the end of the second cycle. However, overall, the observational data shows that the overall component observed shows significant progress from all practical aspects. It can also be said that all students participated positively in the written cycle and the oral process. This can be seen when the researcher allows one of the students representing the group to report the results of their group work and quickly send the results online. Likewise, when asking students to present the recount text orally, which they did in groups. However, the things found in the first cycle related to linguistic aspects as previously mentioned, namely the forms of 'pluralization' and 'singularity,' the students' error rate decreased. This is because the teacher anticipates in advance, according to the findings in the first cycle, by providing examples of the correct use of sentences.

Furthermore, the data obtained from the field notes will be cross-checked with observations. From the results of field notes, students felt motivated to learn as far as the researchers observed. This was evidenced by their discussions before the teaching and learning process took place in the classroom. The atmosphere of the debate on recount texts seemed to be getting more lively to talk about, especially about their respective experiences, which became the conversation. The notes' results also showed how enthusiastic the students were to know the 'recount' texts so that sometimes students showed each other their work. If we compare the notes' results in the first cycle, there are still students who are still indifferent, but in this second cycle, all of them have mingled discussing the results of their respective work. Overall, these field note results are not much different from the data from the several observed components' observations.

Another thing that was obtained from the field notes was that students no longer questioned their vocabulary limitations. Their solutions create their strategies for increasing their vocabulary. So that it can make it easier for them to write recount texts. Sometimes among the students treated, some acted as mentors who gave instructions and taught other students who did not know entirely about compiling a fair and correct 'recount' text. This can be seen from their conversations when they are learning at the same place, which is not far from one student to another. The results of these field notes were precisely the same as in the first cycle.

After implementing literacy-based learning and teaching for three meetings, the researcher gave the students individual tests. Of course, the form of the test given relates to learning a different form of 'recount text' in the first cycle, but the difficulty level is more or less the same. The test results obtained by students can be seen as follows:

Table 4. Second Cycle Student Test Results

\begin{tabular}{llllllll}
\hline \multirow{2}{*}{ No } & Initials & \multicolumn{3}{c}{ SCORE } & \multicolumn{2}{c}{ Category } \\
\cline { 2 - 6 } & & \multicolumn{3}{c}{ Assessment Aspects } & Total \\
\cline { 2 - 6 } & Or. & Ev. & Ro. & Kb. & Very satisfy \\
\hline 1 & DA & 20 & 25 & 20 & 25 & 90 & Good \\
\hline 2 & HR & 20 & 20 & 20 & 20 & 80 & Good \\
\hline 3 & WD & 15 & 15 & 20 & 20 & 70 & Good \\
\hline 4 & DH & 15 & 15 & 15 & 15 & 60 & Good \\
\hline 5 & WS & 20 & 20 & 20 & 25 & 85 & Good \\
\hline 6 & FW & 20 & 15 & 20 & 20 & 75 & Good \\
\hline 7 & HS & 20 & 20 & 20 & 20 & 80 & Good \\
\hline 8 & FF & 20 & 15 & 20 & 25 & 80 & Good \\
\hline 9 & WW & 20 & 20 & 20 & 20 & 80 & Good \\
\hline 10 & RS & 20 & 15 & 15 & 5 & 55 & Good \\
\hline 11 & RA & 15 & 20 & 20 & 20 & 75 & \\
\hline 12 & HA & 20 & 20 & 20 & 25 & 85 &
\end{tabular}

The data above shows that generally, students have increased in writing accurate and correct 'recount' texts. These results can be seen from the scores obtained by students from the given tests. The test results are encouraging and have increased very significantly.

Most students get above a minimum score of 75 . Generally, they are in the successful category. Only two students, or $16.67 \%$, were under the unsuccessful category, in the failing class. These two students were in the unsuccessful category because they had many errors in the 'generic structure' and 'linguistic aspects' of the 'recount text.' These two students have not compiled a 'generic structure' by the composition of the recount text, and there are still many errors related to linguistic aspects. 
On the other hand, students are in the booming category because they have fully understood sentences in the form of 'simple past' and have known 'generic structures' in composing and writing 'recount' texts. They can also place and connect sentences according to the 'event' that occurs using the proper 'conjunction' or 'connective words,' such as the words first, second, then, next, before, after that, and finally. The test results in this second cycle are very encouraging because the researchers followed the data from the reflections conducted by fellow research teams before entering the second cycle. Thus, there was a very significant increase in students' abilities, which can be seen from the scores obtained, namely the average score of the first cycle test results from 43.75 to 76.25 .

\section{Reflection}

The results of three meetings (treatment) in the second cycle, researchers and other fellow researchers analyzed the effects of observations and the consequences of field notes in implementing 'literacy' based teaching and learning, obtained data that what has been mutually agreed upon in the reflection has gone according to approved before doing online education (treatment) to students. Of course, the researcher implemented inputs from the results of the review, including multiplying structured exercises in the form of questions that lead to writing 'recount text'. Give a lot of portions to the JCOT pase. Provide activities to make sentences in the form of 'simple past,' Many of them find mistakes when writing the assigned texts and test results obtained from these students.

\section{Questionnaire Results}

This questionnaire sheet is one of the data collection instruments in this study, besides using observation instruments and field notes that students must fill in by students during the implementation of literacy-based learning and teaching conducted by researchers (teachers) in the classroom. Each student must fill out this questionnaire after the last meeting and after being given the test. Researchers provide instructions on how to fill out the questionnaire clearly so that there are no errors in filling it out. The data obtained from the questionnaire results are as follows:

\section{Table 6. Data Obtained from the Questionnaire}

\begin{tabular}{lll}
\hline No & Questionnaire questions & Answer \\
\cline { 2 - 2 } & Yes & No \\
\hline
\end{tabular}

1 Do the learning techniques applied by researchers online make you enthusiastic and happy to learn?

2. Does the teaching technique apply online to make it easier for you to understand the teaching materials provided?

3, Are you able to make "simple past" sentences?

4. Do you already know and understand the linguistic elements in the 'recount' text?

$\sqrt{ }$

$\sqrt{ }$

5. Do you know the general order of the structure contained in the recount text?

$\sqrt{ }$

6. Do you understand and can use "conjunction" or "connective words" to connect one "event" to the next?

$\sqrt{ }$

7. Do you understand and can write correctly and adequately the Orientation form in a recount text?

$\sqrt{ }$

8. Do you understand and can correctly and adequately write the form 'event' in a recount text?

$\sqrt{ }$

9. Do you understand and can write properly and correctly the form of reorientation in a recount text?

$\sqrt{ }$ 
Based on the data from the student questionnaire results in the table above, it shows that all students feel happy and enthusiastic about learning and the techniques applied by the teacher in the teaching and learning process in the classroom students find it easier to understand the material being taught. The teacher gave a lot of exercises that were felt to be difficult and provided a lot of feedback to the students so that the students ended up being most able to make sentences in the form of "simple past."

Regarding other linguistic elements besides 'simple past,' students can also understand well 'action verbs' and can distinguish 'regular verbs' and 'irregular verbs' and changes from simple to 'past' form. Likewise, the use of "conjunction" or connective words, "which connects an" event "to the next" event "according to the order in which it is ordered.

Furthermore, the questionnaire data shows that all students understand and can distinguish each general structure (generic structure) when writing a 'recount' text, whether based on the personal experience of students or other people's experiences. The students' tests also proved that most of them could write the correct and correct recount text.

The test result data also shows that the average student scores above the average completeness score of 75 . This is in line with the observation data, field notes, and questionnaire data that the students filled out. All students said that with "literacy" based learning and teaching applied by the teacher, it was easier to know and understand the text's writing. This is also evidenced by the results of the test in the second cycle have increased significantly.

\section{Conclusion}

Based on this study's objectives, this study concludes that literacy-based teaching and learning can improve students' ability to understand and write precise and correct recount texts through the teaching process of implementing teaching materials in oral and written forms simultaneously or simultaneously. Also, the increase in students' abilities in applying "literacy" based teaching and learning was very significant; namely, students' scores in the first cycle were an average of 43.75 to an average of 76.25 in the second cycle. Therefore this study recommends that further researchers develop literacy-based teaching and learning to improve students' ability to understand and write recount texts.

\section{References}

[1] Agustien, IR, Helena. (2004). Materi Pelatihan Terintegrasi; Bahasa Inggris. Jakarta: Direktorat Pendidikan Dasar dan Menengah, Departemen Pendidikan Nasional

[2] Brown, H. Douglas. (2001). Teaching by Principles. San Francisco University: A pearson Education Company.

[3] Depdiknas. (2006). Standar Kompetensi Mata pelajaran Bahasa Inggris SMP dan MTS. Depdiknas. Jakarta,

[4] Gunadi H. Sulistyo. (2002). Pengantar Teori dan Aplikasi Penelitian Tindakan Kelas. Jakarta: Direktorat pendidikan Dasar dan menengah, departemen Pendidikan Nasional

[5] Heaton, J.B. (1988). Writing English language Tests. Longman

[6] Kasihani, K.E. Suyanto. (2003). English for Junior High School. Jakarta: Direktorat Pendidikan Dasar dan menengah, Departemen Pendidikan Nasional.

[7] Kemmis, S. dan Mc Taggart, R. (1992). The Action Research Planner. Victoria: Geakin University press

[8] Kern, R. 2000. Literacy and Language Teaching. Oxford University

[9] Kramsch, C. (1993). Context and Culture in Language Teaching. Oxford University press

[10] Sri Widayati. 2002. Paragraph Writing. Jakarta: Direktorat pendidikan Dasar dan Mengenah, Departemen Pendidikan Nasional

[11] Sugiono. (2001). Statistika Penelitian. Alphabeta.

[12] Sulaiman. A. (2003). Improving Writing Skill of the Students SMP Negeri 11 Palu through Games Activities. Universitas Tadulako. 